\title{
Study the Some Semen Parameters of Fertile and Infertile Male in Misan Province
}

\author{
Zeinab A. J. R. Al-Ali ${ }^{*} \quad$ Azhar L. Saied ${ }^{2}$ Nidhal A. Hashim ${ }^{3}$ \\ (1),(2)Department of Biology, College of science, Misan University, Misan, Iraq \\ (3) Southern Technical University, Technical institute - Amara, Misan, Iraq \\ *E-mail of the corresponding author:Zainab.alali@yahoo.com
}

\begin{abstract}
Background: Infertility in human is described as a situation in which a couple (male and female) does not succeed in achieving pregnancy despite of unprotected sexual intercourse over a period of 12 months. The aim of the current study was to collect and analyses quantitative baseline data about the males suffering from the impaired infertility in Misan province. Material and Methods: semen samples have been collected and examined for 60 married male suffering from impaired fertility group and 19 health's married male as a control. Results: In regards to the mean volumes of seminal fluid and the $\mathrm{pH}$ values, the results showed that there were no statistically significant difference between infertile and control group. However, the results revealed the differences between the control and the infertile groups were highly significant for the total sperm count ( $p<$ 0.01).In terms of the percentage of normal and abnormal sperm morphology, were no significant differences between the control and the infertile groups. The percentage of active sperm motile was significant $(p<0.05)$ in the control group compared with the infertile group. While the percentage of non motile sperm was significant $(\mathrm{p}<0.05)$ in non fertile males in comparison to the males in the control group. Differences between the control and the infertile groups were non-significant regarding the percentage of weakness and sluggish sperm. The varicocele was the higher percentage while hormonal disorder was the lower percentage than the other causes. The incidence of infertility was more common among men in urban population compared with infertile men in rural population with a significant difference of $(\mathrm{p}<0.01)$.
\end{abstract}

Key words: semen, fertile, subfertile, male, Misan

DOI: $10.7176 / \mathrm{JMPB} / 57-04$

Publication date: July $31^{\text {st }} 2019$

\section{Introduction}

Infertility in human is described as a situation in which a couple does not succeed in achieving pregnancy despite of unprotected sexual intercourse over a period of 12 months (Parsanezhad et al.,2013 ; Punab et al., 2017). Infertility is a well known health issue affecting all over the world, it present a particularly vexing clinical problem, it affects about $15 \%$ of couples trying to have a child (Agarwal, et al., 2015). Infertility in male is defined as the inability of the male reproductive cells to produce mature, actively motile and functional spermatozoa in sufficient amount that will ensure fertilization of a released ovum in the fallopian tubes of the female (AL Basher,2016). Impaired fertility of the male is causative in $20 \%$ of infertile couples and contributory in up to another $30-40 \%$ (Ferlin et al.,2006 ). There are many factors that are associated with infertility in men other than the healthiness of the spermatozoa. These could include the presence of varicocele, sexual dysfunction, genital tract infection, inflammation and urospermia. Age, nutrition, hormonal disorder, chromosomal abnormalities, stress and emotions, excessive alcohol consumption, environmental factors and non- diagnosable causes could be the possible factors that may affect the male infertility (Olooto, 2012; Skakkebaek et al., 2016 ; Salas-Huetos et al.,2017).

The differences in sperm characteristics between fertile and infertile men were first reported by Macleod and Gold (1951 a;1951 b). Semen parameters are considered in different methods on the basis of the clinic settings: as part of infertility examination or follow up of infertility treatment (Zinaman et al.,2000). The world health organization manual for the examination of human semen and sperm, cervical mucus interaction (WHO, 1992; WHO, 1999) provides guidelines for assessment many semen parameters ; However, it is still difficult to compare the results between different laboratories. Furthermore, many studies have indicated that the geographical differences in semen quality may be related to environmental factors, ethnic or genetic differences (Kamieniczna et al.,2015; Ayad et al.,2018). In many provinces in Iraq, semen analysis is routinely done through the conventional microscopy method, culture, hormonal evaluation and special sperm function tests. Clinical evaluation of seminal quality is linked to the ability to predict the fertility aspects such as, identify the causes of infertility and detect changes in potential fertility (WHO, 1992). The aim of the current study was to collect 
baseline information about the patients suffering from the infertility in Misan province .

\section{Materials and Methods}

\section{Study design and subjects}

This study was carried out in Al-Sadder general hospital / Maysan province for the period between 15 / 10 / 2013 to $15 / 3$ / 2014 , the samples were collected from 60 married male suffer from impaired fertility at age group of (18 - 42) year, and 20 married male as a control age group of ( $21-45)$ year.

\section{Semen analysis}

All the semen samples were examined for physical parameters such as. Volume, $\mathrm{pH}$.In addition, the percentage motility and sperm concentration were analyzed according to the standard WHO parameters (WHO,2010).

\section{Statistical analysis}

The Statistical analysis was calculated for the study results by SPSS (2001).

\section{Results}

This study was carried out on infertility hospitalized population of 60 patients in Maysan province and 20 men as a control. The mean volumes of seminal fluid were $3.3 \mathrm{ml}$ for the control group and $3.1 \mathrm{ml}$ for the patients group. The $\mathrm{pH}$ value was 8.4 in the control group while it was recorded 7.9 in the patients group. The differences between the control and patients groups were high significant $\mathrm{p}<0.01$ for the total sperm count (mean 103.33 and $46.96 \times 10^{6}$ ), as shown in table (1).

The difference between normal and abnormal sperm morphology were non-significant for the control and infertile group percentages $(78.68 \%$ and $69.58 \%$ for the normal sperm morphology; $21.32 \%$ and $30.42 \%$ for abnormal sperm morphology) as shown, as shown in in table (2).

The percentage of active sperm motile was significant $(\mathrm{p}<0.05) 30.40 \%$ for the control group compared with the infertile group ( $8.93 \%)$. While the percentage of non motile sperm was significant $(p<0.05) \quad 42.47 \%$ for infertile group compared with the control group (19.60\%). Differences between the control and the infertile groups were non significant for the percentage of weak and sluggish sperm $(25.67 \%$ and 18.38 for the weak sperms, $24.33 \%$ and $30.22 \%$ for the sluggish sperm), as shown in table (3).

The percentage of the diseases distribution in the infertile group is shown in table (4). varicocele was the highest ( $43.33 \%$ ) and hormonal disorder was the lowest ( $20 \%$ ), while the non causes recorded $6.67 \%$ percentage . The incidence of infertile men was significant $83.3 \%(\mathrm{p}<0.01)$ in urban population than in rural population $16.7 \%$ table(5).

\section{Discussion}

In this study, semen from men who suffered infertility was analyzed in order to establish reference values for semen parameters. Semen analysis though routinely used to evaluate the male partner in an infertile married status. Sperm measurements that vacillated between fertile and infertile values are not well defined (Morin and Scott, 2018). The comparison of the differences in a control and infertile population for semen variables can be examined in most laboratories (Ali and Abboud, 2014). For sperm concentration, many studies have maintained a large and overlapping distribution in the fertile (control and subfertile) population (Lee et al., 2012; Levine et al., 2017) .Olajuba et al. (2013) found that nearly 51.5\% whose sperm concentration below $20 \times 10^{6}$ cell $/ \mathrm{ml}$ could equally be a source or could contribute in infertility. In another study, $42.5 \%$ of the subjects had a sperm count of less than $20 \times 10^{6}$ cell $/ \mathrm{ml}$, while $53.2 \%$ had sperm motility of less than $50 \%$ (Loto, 2004). The WHO changed its cut - off value for normality (from 50 to $30 \%$ ). Surprisingly, this change was not based on any biological data - yet another reason to investigate the power of sperm morphology to predict subfertility in vivo (Omscbelet et al., 1997). The etiology of male infertility in the population seems to be unrelated to sperm volume but related to sperm count, motility and morphology (Nwafia et al., 2006). In this study the value of $\mathrm{pH}$ in semen for fertile men is agreement with the study by Haugen et al.(2006) which found the $\mathrm{pH}$ of Norwegian fertile men is 8.3 .

Urogenital tract infection in male is one of the important causes for men infertility. The results in this study is in agreement with the results of Golshani et al. (2006) and Ekwere et al. (2007) they found the urogenital 
infections are one of the causes of infertility among male. In this study the percentage of urogenital infection among men was $43.33 \%$ while in study by Ekwere et al. (2007) the percentage of urogenital infection was recorded $34.7 \%$. The etiological role of infection in male infertility has been paid attention in recent years. The seminal fluid constituted is an important medium for the spread of various infective agents, and those genital infections through sexual and nonsexual pathway may be responsible for a high percentage of infertility (Abarikwu, 2013). Endocrinology is the presence of an abnormality in the serum hormonal panel without necessarily implying a primary endocrine cause of infertility. Endocrine abnormalities are common in azoospermic infertile males. Other causes of male infertility include societal pressure leading to psychological problems. Psychological factors and stress - induced changes in heart rate and cortisol are predictive of a decreased probability of achieving a viable pregnancy (Sheiner et al.,2003).

\section{Conclusion}

The infertility is a concerned health and social problem in the studied population. These data may provide useful information to help these men.

\section{References}

Abarikwu SO. (2013) . Causes and risk factors for male. Factor infertility in Nigeria : A review . Aferican J. of Reprod. Health, 17(4):150- 166.

Agarwal, A.; Mulgund, A.; Hamada ,A .; and Chyatte, M. R.(2015). A unique view on male infertility around the globe. Reproductive Biology and Endocrinology, 13:37.

AL Basher ,M. A. M.(2016). Gram Positive Bacteria and their Effects on some Semen Parameters of Infertile Men attending Gezira Fertility and Infertility Reproductive Center, Gezira State, Sudan (2015- 2016). A Dissertation in Medical Microbiology, University of Gezira, Sudan :1-62 pp.

Ali, M. M. and Abboud, H. A. ( 2014) . Pattern of seminal fluid analysis among subfertile couples in Kerbala Maternity Hospital during 2012. Karbala J.Med.7 (2):1865-1869.

Ayad, M.B.; Horst, G.V.; Plessis, S.S.(2018). Short abstinence: A potential strategy for the improvement of sperm quality. Middle East Fertility Society Journal 23 : 37-43.

Ekwere PD, Archibong EE, Bassey EEetal.( 2007) . Infertility among Nigerian couples as seen in Colabar .Port .Harcourt Med J., 2: 35- 40.

Ferlin A, Arredi B and Foresta C.( 2006). Genetic causes of male infertility. Reprod. Toxicol.22 (2): 133-141.

Golshani M, Taheri S, Eslami G, Suleimani Rahbar AA, Fallah F and Goudarzi H .( 2006) . Genital tract infection in asymptomatic infertile men and its effect on semen quality. Iranian J.Publ. Health, 35(3) : 81- 84.

Haugen TB, Egeland T and Magnus $\Theta$. (2006) .Semen parameters in Norwegian fertile men . J. of Androl., 27( 1) : 66- 71 .

Kamieniczna, M.; Fraczek ,M.; Malcher ,A.; Rozwadowska, N. ; Czernikiewicz ,A. ; Jedrzejczak, P. ; Semczuk, M..(2015). Semen Quality, Hormonal Levels, and Androgen Receptor Gene Polymorphisms in a Population of Young Male Volunteers from Two Different Regions of Poland. Med Sci Monit, 21: 2494-2504.

Lee, H. D. ; Lee, H.S.; Park, S.H,.; Jo , D.G. ;Choe, J.H.; Lee, J.S.; and Seo ,J.T. (2012) Causes and classification of male infertility in Korea .Clin.Exp. Reprod.Med.,39(4):172-175 .

Levine, H.; Jørgensen ,N.; Martino-Andrade, A.; Mendiola, J.;Weksler-Derri, D.and Mindlis, I.(2017). Temporal trends in sperm count: a systematic review and meta-regression analysis. Human Reproduction Update, 23(6) : 646-659,

Loto, O.M.( 2004) .Profile of the semen analyses of male partners of infertile couples in a Nigerian population . Int . Congress Series, 1271:57- 59.

Macleod, J. and Gold, R.Z.( 1951 a) .The male factor in fertility and infertility П. spermatozoon counts in 1000 men of unknown fertility and in 1000 cases of infertile marriage .J. Urol ., 66: 436- 449 . 
Macleod J and Gold RZ( 1951 b) .The male factor in fertility and infertility IV. Sperm morphology in fertile and infertile marriage .Fertil. Steril. , 2: 394-414.

Morin, S. J. and Scott, R.T. (2018). Knowledge gaps in male infertility: a reproductive endocrinology and infertility perspective. Transl. Andro.l Urol. 7 (Suppl 3):S283-S291.

Nwafia, W.C.; Igweh, J.C.; and Udebuani, I.N.( 2006).semen analysis of infertile Igbo males in Enugu, Eastern Nigeria . Nig. J. Physiol. Sci.,21:67-70 .

Olajuba FA, Mope DA, Osinupebi OA, Jagun OE.( 2013) .Seminal fluid characteristics of men attending infertility clinic of a teaching hospital . Open Journal of medical microbiology, 3: 1- 4 . Olooto, W.E.(2012). Infertility in male; risk factors, causes and management- A review. J. Microbiol. Biotech. Res., 2 (4):641-645 .

Omscbelet W, Bosmans E, Janssen M, Cox A, Vlasselaer J ,Gyselaers W, Vandeput H, Gielen J , Pollet H, Maes M, Steeno O, and Kruger T.( 1997 ) .Semen parameters in a fertile versus sub fertile population : need for change in the inter _ pretation of semen testing. Human Reprod ., 12 ( 5) : 987- 993.

Parsanezhad, M.E.; Jahromi, B.N.; Zare. N.; Keramati, P.; Khalili, A.; and Parsa-Nezhad,M.(2013) .Epidemiology and Etiology of Infertility in Iran, Systematic Review and Meta-Analysis. J Womens Health Issues Care 2 (6):2-6

Punab M.; O. Poolamets; P. Paju; V. Vihljajev; K. Pomm; Ladva, R.; P.Korrovits1and M. Laan.(2017). Causes of male infertility: a 9-year prospective monocentre study on 1737 patients with reduced total sperm counts. Human Reproduction, 32, (1): 18-31

Salas-Huetos, A.; Bulló ,M.; Salas-Salvadó,J.(2017). Dietary patterns, foods and nutrients in male fertility parameters and fecundability: a systematic review of observational studies. Human Reproduction Update, 23 ( 4): 371-389.

Sheiner EK, Sheiner E, Hammel RD et al (2003). Effect of occupational exposures on male fertility: Literature Review. Industrial Health, 41: 55-62.

Skakkebaek, N.E.; Meyts, E.R.; Louis, G .M.; Toppari, J.; Andersson, A.M. ;Eisenberg, M.L .; Jensen, T.K.; Jørgensen, N.; Swan, S. H.; Sapra, K.J.; Ziebe, S.(2016).Male reproductive disorders and fertility trends :influences of environment and genetic susceptibility . Physiol Rev ;96(1):55-97.

Statistical packages for the social sciences.(2001). Statistical software for windows version 13.0 Microsoft. SPSS ${ }^{2}$, Chicago, IL, USA.

World Health Organization ( 1992) .Laboratory manual for the examination of human semen and sperm cervical mucus interaction $.3^{\text {rd }}$.ed. , Cambridge , UK, Cambridge university press.

World Health Organization ( 1999) .Laboratory manual for the examination of human semen and sperm cervical mucus interaction $4^{\text {rd }}$.ed. , Cambridge, UK, Cambridge university press.

World Health Organization (2010) .Laboratory manual for the examination and processing of human semen $.5^{\text {th }}$ ed. Geneva, 264 pp.

Zinaman MJ ,Brown C C , Selevan SG and Clegg ED ( 2000). Semen quality and human fertility :a prospective study with healthy couples. J. Androl. , 21: 145- 153. 
Table (1): Semen parameters in the patients and the control groups.

\begin{tabular}{|c|c|c|c|}
\hline Parameters & Patients group & Control group & P value \\
\hline \hline Volume ( ml) & 3.1 & 3.3 & NS \\
\hline $\mathrm{pH}(\mathrm{unit})$ & 7.9 & 8.4 & $\mathrm{NS}$ \\
\hline Count (sperm/ $\left.10^{6}\right)$ & $46.96 \pm$ & $103.33 \pm$ & 0.01 \\
& 11.42 & 24.09 & \\
\hline
\end{tabular}

Table(2): Percentage distribution of sperm morphology.

\begin{tabular}{|r|c|c|c|}
\hline Morphology (\%) & $\begin{array}{c}\text { Patients } \\
\text { group }\end{array}$ & Control group & \multirow{2}{*}{ P value } \\
\hline \hline Normal & 69.58 & 78.68 & \multirow{2}{*}{ NS } \\
\hline Abnormal & 30.42 & 21.32 & \multirow{2}{*}{100} \\
\hline Total & 100 & 100 & \\
\hline
\end{tabular}

Table (3): Percentage distribution of sperm motility.

\begin{tabular}{|r|c|c|c||}
\hline Motility (\%) & $\begin{array}{c}\text { Patients } \\
\text { group }\end{array}$ & $\begin{array}{c}\text { Control } \\
\text { group }\end{array}$ & P value \\
\hline \hline Active sperm & 8.93 & 30.40 & 0.05 \\
\hline Weak & 18.38 & 25.67 & $\mathrm{NS}$ \\
\hline Non motile & 30.22 & 24.33 & $\mathrm{NS}$ \\
\hline Total & 42.47 & 19.60 & 0.05 \\
\hline
\end{tabular}


Table (4): percentage distribution of the diseases in the infertile group

\begin{tabular}{|r|c|c|c||}
\hline \multicolumn{1}{||r||}{ Diseases } & Number & Percentage \% & P value \\
\hline Varicocele & 26 & 43.33 & \multirow{2}{*}{0.01} \\
\hline genital tract infection & 18 & 30 & \\
\hline hormonal disorder & 12 & 20 & \\
\hline non causes & 4 & 6.67 & \\
\hline Total & 60 & 99.99 & \\
\hline
\end{tabular}

Table (5): percentage distribution of the infertile men according to the area

\begin{tabular}{|r|c|c||}
\hline \multicolumn{1}{|c|}{$\begin{array}{l}\text { Infertile men } \\
\text { Population }\end{array}$} & Urban & Rural \\
\hline Percentage ( \% ) & 83.3 & 16.7 \\
\hline Total & \multicolumn{2}{|c|}{100} \\
\hline
\end{tabular}

